weise auf den eigentlichen Sinn geschlossen wird. Mitunter nimmt diese Erkenntnisweise auch präskriptive Züge an, etwa wenn Anke Beger den metapherngesättigten Erklärungsversuch eines Lehrenden kritisiert: „the professor seems to confuse source and target domain“ (362). Welchen Erkenntnisgewinn erfüllt eine Herangehensweise, die auf einen Konkretismus hinausläuft, der besagt: uneigentlicher menschlicher Ausdruck erschöpft sich in der Rückführung auf greifbare physische Prozesse? Wie der Beitrag von Mihály Szívós vorführt, kann das Prinzip der Konkretisierung noch um eine biologische Dimension erweitert werden: Hier wird die
Fähigkeit zur Metapher auf ein frühes phylogenetisches Entwicklungsstadium zurückgeführt, in dem ontologische Ähnlichkeiten zwecks Arterhaltung wahrgenommen werden.

Mit seiner Methodenvielfalt illustriert dieser Sammelband die unterschiedlichen, oft antagonistischen Epistemologien, an der sich zeitgenössische Forschung entzündet. Oder um es mit Lakoff zu sagen: MetAPHERN SIND BRENNSTOFF.

JOHANNES D. KAMINSKI Institut für Weltliteratur SAW Slowakische Republik ORCID: https://orcid.org/0000-0002-9357-1149

\title{
PETER ŽIAK: Estetika naratívnych textov [Aesthetics of narrative texts]
}

Nitra: Univerzita Konštantína Filozofa, 2021. 167 s. ISBN 978-80-558-1714-9

DOI: https://doi.org/10.31577/WLS.2021.13.4.15

Monografia Petra Žiaka Estetika naratívnych textov navracia do teoretickej reflexie zásadné a stále aktuálne otázky o fungovaní fikčných naratívnych textov. Uchopenie povahy fikčného naratívu predstavuje východisko skúmania čitatel'skej estetickej skúsenosti. Zážitkovost' literatúry a procesy s tým súvisiace stoja $\mathrm{v}$ popredí záujmu autora, ktorého formovalo štúdium estetiky a francúzskej literatúry na pracovisku stavajúcom na tradícii nitrianskej školy.

Práca vychádzajúca $\mathrm{z}$ prístupov štrukturalizmu, semiotiky a recepčnej teórie pozostáva zo štyroch kapitol, v ktorých autor systematicky a precízne predkladá poznatky z oblasti literárnej teórie, pričom ich aplikuje aj prakticky na texty $\mathrm{z}$ francúzskej literatúry. Na rozdiel od všeobecne prevládajúcej orientácie na obsahové a formálne vlastnosti textu sa tažiskovo upriamuje na skúmanie účinkov literárneho textu na recipienta. Neodmieta však ani samotnú textovú analýzu. Ba práve naopak. Interpretácia estetického zážitku z čítania podla neho predpokladá najskôr dôkladné porozumenie textúre fikčného textu. Kritické zhodnotenie doterajšieho teore- tického uvažovania o predmetnej problematike v tom zmysle, že autor neraz zaujme iné alebo len čiastočne súhlasné stanovisko so závermi niektorých teoretikov, svedčí jednak o komplexnosti spracovanej témy, v ktorej je podstatná tak objektívna zložka (naratívne štruktúry fikčných textov), ako aj subjektívna (pôžitok z čítania ako značne individuálna záležitost'), jednak o dobrej znalosti odbornej literatúry, invencii a odvážnom prístupe autora monografie k textu.

Prvú kapitolu monografie logicky otvára problematika fikčných svetov, ktoré autor chápe ako konštrukty fikčného textu. Usúvztažňujúc teóriu fikčných svetov (Lubomír Doležel, Thomas Pavel) s tézami mimetickej teórie si všíma predovšetkým výpovednú hodnotu tvrdení o fikčnom svete, indikátory fikčnosti a problém referencie, čo ho privádza $\mathrm{k}$ hladaniu rozdielov medzi fikčnými a faktuálnymi textami. Osobitne sa $\mathrm{v}$ tejto súvislosti venuje postaveniu mýtu a historického textu. Spolu s teoretikmi konštatuje absenciu formálnych diferenciačných znakov, ktoré by odlíšili fikčný naratív od historického, a hovorí o uplatňovaní istých konvencií 
vnímania textu. Zásadným rozdielom medzi fikciou a históriou je však autorský zámer, ktorý je v prípade historika na strane rešpektovania faktov a pravdepodobnosti. Problematiku mimézis fikcia neraz vyhrocuje, ako autor ilustruje na príkladoch $\mathrm{z}$ francúzskeho literárneho realizmu 19. storočia. I ked', ako je známe, fikčný text nemá schopnost' odkazovat' na aktuálny svet, neznamená to, že fikcia naň vplyv nemá. Podla Žiaka sa fikčným svetom $\mathrm{v}$ súčasnosti pripisuje referenčný rámec ohraničený výpoved’ami textu. Práve konkrétna textúra ovplyvňuje čitatel'skú recepciu a podnecuje estetický zážitok.

$\mathrm{V}$ druhej kapitole autor problematiku prehlbuje skúmaním naratívnych (intenzionálnych) štruktúr, ktoré považuje za nosné prvky estetickej pôsobivosti, no vníma ich $\mathrm{v}$ súhre s referenčnou realitou textu, alebo, povedané slovami Doležela, s extenzionálnymi štruktúrami. Východiskom skúmania naratívnej textúry sú niektoré základné princípy literárnovedného štrukturalizmu (Jurij Lotman), naratológie (Seymour Chatman, Roland Barthes, Umberto Eco, Gérard Genette) a Aristotelovej Poetiky. Autor, ktorý aplikuje štrukturálno-semiotický prístup a opiera sa o analýzu naratívneho diskurzu v práci Gérarda Genetta Discours du récit (Diskurz rozprávania, 1972), sa, podobne ako samotný Genette, usiluje o deskripciu naratívnych kategórií v Proustovom románe Hledání ztraceného času (2012; À la recherche du temps per$d u, 1913$ - 1927). Na konkrétnych ukážkach románu si všíma usporiadanie deja (ordre), trvanie/tempo (durée), frekvenciu (fréquence), naratívny spôsob (mode) a s tým spojenú dištanciu (distance) a fokalizáciu (focalisation - nulovú, externú, multiplikovanú, internú) a nakoniec hlas (voix - extradiegetický, intradiegetický, homodiegetický, heterodiegetický). Žiak konštatuje, že je to práve špecifická textúra, v Proustovom prípade kombinácia istého typu fokalizácie, rozprávača a časovej dištancie, ktorá vytvára esteticky relevantný význam.

Recepcia z hladiska textuálnej semiotiky je predmetom tretej kapitoly, $\mathrm{v}$ ktorej autor ide ponad rámec textu a vychádzajúc $\mathrm{z}$ teó- rií Umberta Eca, Jonathana Cullera, Terryho Eagletona či Františka Mika sa zamýšla nad perspektívou čitatela a hladá súvislosti medzi štruktúrou textu a estetickým zážitkom. O recepcii literárneho textu uvažuje $\mathrm{z}$ perspektívy literárnej teórie všeobecne, napríklad ked prostredníctvom Ecovho pojmu kritická interpretácia poukazuje na význam metajazyka (naratologického pojmoslovia) pre pochopenie účinku určitého typu textu, ktorý generuje modelového čitatela a určuje hranice jeho interpretácie. Čitatel' v procese recepcie formuluje hypotézy („topiky“ - Eco), pričom čerpá aj $\mathrm{z}$ mimotextovej encyklopédie („,inferenčné potulky“ - Eco), ale primárne vychádza $\mathrm{z}$ indícií fikčného textu. Autor sa zaoberá aj literárnymi konvenciami, resp. čitatelskými kompetenciami podla Cullera, ktoré ho privádzajú $\mathrm{k}$ uvažovaniu o literatúre (literatúra ako stanovisko $\mathrm{k}$ problémom človeka a jeho vztahu k svetu, nezainteresovanost' literatúry, text ako vnútorne štruktúrovaný systém). Konkrétne skúma Žiak literárny text $\mathrm{z}$ hladiska Mikovej koncepcie výrazových kategórií a vychádza $z$ jeho odmietania umeleckého jazyka ako takého. Estetickú pôsobivost' podla Mika určuje konfigurácia výrazových polôh (kontrast rušivého a vyrovnávajúceho prv$\mathrm{ku}$ ), ktoré prenikajú do témy a determinujú jej tenzívno-detenzívny charakter. Autor si ich všíma v poetike už spomínaného Proustovho románu.

Uvedené poznatky Žiak zohladňuje v poslednej, ale klúčovej štvrtej kapitole, v ktorej predkladá teóriu estetickej skúsenosti ako skúsenosti hedonistickej. Jeho výklad sa opiera predovšetkým o teórie estetickej skúsenosti Františka Mika (teória estetického zážitku), Jeana-Mariho Schaeffera (estetická skúsenost' ako skúsenost' hedonistická) a Raphaëla Baroniho (naratologická koncepcia). Uvažovanie o estetickej skúsenosti iniciuje interpretácia vlastného čitatel'ského zážitku autora $\mathrm{z}$ prvého čítania francúzskeho románu Velký tulák (1965; Le Grand Meaulnes, 1913) Alaina-Fourniera, ktorý je príbehom o dospievaní, konflikte zidealizovaných predstáv o živote a skutočnosti, ako aj o hodnotách lásky a priatel'stva. Spro- 
stredkovanie pozitívnych hodnôt $\mathrm{v}$ románe označené francúzskou literárnou vedou ako "romanesque blanc“ (dôraz na mravné ideály človeka) v protiklade $\mathrm{k}$,romanesque noir“ (dôraz na ludské neresti) predstavuje, podla autora, vo všeobecnosti naše očakávania od literatúry, čo priamo súvisí s otázkou hodnoty literárneho diela. Žiak konštatuje, že parciálne hodnoty, ktoré nadobúdame $\mathrm{v}$ procese recepcie, nemusia vždy korelovat's hodnotami po ukončení recepcie, že pôžitok z čítania môžeme mat' aj vtedy, ked' sa nestotožňujeme s hodnotovými postojmi postáv a že esteticky na nás môžu pôsobit aj prvky nesúvisiace so zameraním témy na životný problém, ako tvrdil Miko. Hedonizmus chápe v zmysle nachádzania potešenia zo samotného čítania, ktoré je základom estetického zážitku, pričom takáto (estetická/hedonistická) skúsenost' predpokladá aj istú estetickú dištanciu, teda odstup a sebareflexiu recipienta, ktorý si uvedomuje, ako na neho predmet pôžitku pôsobí. Vedomé prežívanie pozitívnych, ale aj negatívnych emócií v procese recepcie, je cielom estetickej skúsenosti. Žiak zdôrazňuje, že pri recepcii fikčných textov projektujeme fikčné ,ja“, prežívame fikčné životné situácie a uvedomujeme si ich fikčnost', no naše emócie s tým spojené (zvedavost', napätie, prekvapenie) sú skutočné, rovnako ako sú skutočné aj naše kognitívne schopnosti, ktoré do procesu recepcie zapájame. Práve vedomie fikčnej povahy fikčného naratívu, ktorý odkazuje na vlastný svet, zintenzívňuje estetický zážitok. Hedonistickú teóriu estetického zážitku autor následne ilustruje na postmodernej poviedke Woodyho Allena „Postava Kugelmasse“ (2018; „The Kugelmass Episode“, 1977), ktorá je paródiou na Flaubertov román Pani Bovaryová. Estetickú prítažlivost' nachádza v ozvláštnení poviedky, ktorá prostredníctvom intertextuálnych hier modifikuje vysoko hodnotené dielo (Pani Bovaryová) a posúva ho do novej významovej a výrazovej roviny.

Azda by som mohla zdôraznit, že autor nevyzdvihuje hedonistický prístup $\mathrm{k}$ literatúre na úkor intelektuálneho. Už v úvode zdôrazňuje komplexnost' estetického zážitku a odmieta jednostranné nazeranie na literárny text. Primárne ho však zaujíma pôžitok ako všeobecne zaznávaný a tažko uchopitelný aspekt recepčnej skúsenosti, čo vysvetluje obmedzenia tradičných literárnych koncepcií. Práve ten podla neho významnou mierou stimuluje proces čítania a vôlu recipienta $\mathrm{v}$ ňom zotrvat'.

Čitatel'sky prítažlivá a pojmovo nasýtená monografia Petra Žiaka je presvedčivou ukážkou kritického teoretického myslenia na úrovni efektívneho narábania s aktuálnymi poznatkami, prekonávania ich obmedzení a hladania uspokojivých riešení. Napriek niekol'kým drobným edičným chybám (napr. v interpunkcii) a mechanickému používaniu mena Marcel $\mathrm{v}$ prípade rozprávača Proustovho románu (autor v úvode tvrdí, že Proust sa stráni pomenovat’ rozprávača a sám pritom $\mathrm{v}$ texte označuje rozprávača menom Marcel) považujem Estetiku naratívnych textov za prínosný a obohacujúci príspevok do súčasného literárnovedného diskurzu, ktorý môže nájsţ širšie uplatnenie $\mathrm{v}$ interdisciplinárnom dialógu.

SILVIA RYBÁROVÁ

Ústav svetovej literatúry SAV

Slovenská republika

ORCID: https://orcid.org/0000-0003-4688-0982 